Jelisaveta F. Šafranj'

Faculty of Technical Sciences, University of Novi Sad

\author{
Aleksandra G. Gojkov Rajić
}

Preschool Teacher Training College "Mihailo Palov", Vršac

Marina M. Katić

Faculty of Technical Sciences, University of Novi Sad
UDK-159.953.3.072:81'243-057.875

159.922.072-057.875

DOI: $10.5937 /$ nasvas 18011475

Оригинални научни рад

НВ год. LXVII 1/2018

\title{
THE EFFECTS OF STUDENTS' META-COGNITIVE ABILITIES AND GENDER ON THE DEVELOPMENT OF THEIR FOREIGN LANGUAGE SKILLS
}

\begin{abstract}
This study of meta-cognitive abilities and their impact on the development of foreign language skills makes a significant contribution to research into foreign language teaching and learning in general. The study presented in this paper was carried out on a large sample of university students in Serbia, illustrating its relevance to this educational setting. The study looks at the use of metacognitive strategies examined through the Strategy Inventory for Language Learning (SILL) questionnaire (Oxford, 1990) as well as the effects of gender on the development of students' language skills, as reported through self-assessment. Five out of nine elements of meta-cognitive strategy were found to be predictive of self-assessment of language skills. This finding supports the assumption that the use of meta-cognitive strategies is important in building language skills. However, the study failed to discover evidence of differences in learning strategy use between genders, since only one out of nine elements was found to be statistically significant. The study found a relationship between gender and students' perception of their own language skills. Men scored higher than women on all four variables, which means they assessed their own language skills better than the women did. The pedagogical implications are to consider didactic instructions that would encourage students to identify a problem in foreign language learning and to realize the ways in which actions are regulated, which would lead to a solution of the problem.
\end{abstract}

Keywords: gender, meta-cognitive strategies, foreign language learning, language skills

\section{Introduction}

Successful language learners have a wide variety of thinking skills. Since they are conscious of their knowledge, they know where, when, and how to apply it to any learning situation. Researchers agree that successful learners possess meta-cognition, i.e. the conscious ability to recognize their own knowledge, and to understand and have control over their own learning (Gojkov, 2010). Students with good meta-cognition are able to direct and monitor their own learning processes, and they have the ability to master information and apply learning strategies to solve problems more easily. The notion of meta-cognition originated in the 1970s in the context of information processing studies. The term is most often linked to John Flavell (Flavell, 1976; 1979), who found that a wide

1 E-mail: savetas@uns.ac.rs 
spectrum of cognitive production occurs through the actions and reactions of four classes of phenomena: meta-cognitive knowledge, meta-cognitive experiences, goals and tasks, and actions or strategies.

Meta-cognitive knowledge and abilities concern the individual's awareness of their cognitive processes (observation, memory, thinking), as well as the awareness of when and in which situations deploying a particular learning strategy can be more effective and better than other learning strategies, which may be more effective in other situations and in solving other problems (Gojkov, 2008). The significant aspects of meta-cognition fulfill the function of intellectual processes, meaning they regulate and control behavior while solving a problem (Gojkov \& Stojanović, 2011). Also students who have a greater ability to monitor and manage their learning and problem-solving strategies in addition to their cognitive processes usually achieve better learning outcomes. Students who have developed the ability to manage their learning, learning strategies, and learning achievements as a whole are able to monitor the learning process from beginning to end, and such learning is deeply meaningful and goal-oriented (Goh, 2008).

\section{Language learning and meta-cognitive abilities}

Research into language learning, meta-cognitive knowledge, and students' strategies in particular, has found a mutual influence in terms of second language learning (Zhang \& Goh, 2006) and points to the fact that meta-cognitive abilities should be integrated into students' learning activities to make their learning more efficient (Wenden, 1998). Students' meta-cognition can directly affect the procedure and final result of a learning activity (Bolitho et al., 2003; Purpura, 1997; 1998; Zimmerman \& Schunk, 2001). Therefore, scholars (Birjandi, Mirhassani \& Abbasian, 2006) have attempted to identify certain characteristics of good language learners and the type of strategies they use in language learning assignments. Research (Mahmoudi \& Khonamri, 2010) has found that the major determiner of language learning efficiency is explicit meta-cognitive ability regarding assignment characteristics and the application of appropriate strategies for explaining an assignment. This is due to the fact that meta-cognitive strategies enable learners to be actively engaged in a learning activity (Chari, Samavi \& Kordestani, 2010), as well as to deal with and manage their learning. Also, they enable them to use the best approach to practice their language skills and develop their language learning objectives. Thus, they benefit from their learning activity while processing and storing new information (Boekaerts, Pintrich \& Zeidner., 2000; Eilam \& Aharon, 2003; Mokhtari \& Reichard, 2002; Palmer \& Goetz, 1988). As a result, they obtain better learning outcomes, examination results, and better achievement (Mokhtari \& Reichard, 2002; Zimmerman \& Schunk, 2001).

The results of research into language learning strategies (Anderson, 2003; Rasekh \& Ranjbary, 2003) that investigated the habits of proficient and successful language learners while writing, reading, listening, and speaking support a conclusion that, in comparison to less proficient learners, successful learners take conscious steps to understand what they are doing by using a wider range of strategies. Similar results were found in studies that investigated listening among second language learners. (Goh 1998; 1999; O'Malley, 
Chamot \& Küpper, 1989). Other studies have reported that high degrees of meta-cognitive knowledge allow students to better process and store new information, and to find the best ways to exercise and reinforce what they have learned (Vandergrift, 1996, 1997; Vandergrift, Goh, Mareschal \& Tafaghodtari, 2006; Young, 1997). In addition, meta-cognitive abilities develop thinking (Sternberg, 1998) and comprehension skills (Costa, 2001; Wenden, 1998). Likewise, meta-cognitive awareness characterizes language learning approaches (Baker \& Brown 1984; Nickerson, Perkins \& Smith, 1985), improves learning results (Dickinson, 1995; Zimmerman \& Bahdura, 1994), helps in better recollection of knowledge (Nickerson et al., 1985), writing abilities (Schommer, 1990), and the successful completion of learning assignments (Pintrich, Marx \& Boyle, 1993), enhances progress in language learning, and improves students' cognitive thinking (Vann \& Abraham, 1990).

Some studies have reported that cognitive and meta-cognitive strategies are used more often than other learning strategies, and that intermediate to advanced students use learning strategies more often than other students (Lachini, 1997). Tajedin (2001) looked at language learning strategies in relation to gender, learning situation, and language proficiency, and found that meta-cognitive strategies were used more frequently, and affective strategies less frequently, in comparison with other learning strategies. In addition, the study reported similarities between men and women in their use of learning strategies. Akbari (2003) examined the relationship between the use of language learning strategies and students' foreign language proficiency, and found that meta-cognitive strategies are the most frequently used strategies, and proficient students use meta-cognitive, cognitive, and compensation strategies more often than other strategies. Zare and Sarmadi (2004) looked at the difference between strong and weak university students in their meta-cognitive knowledge and awareness of meta-cognitive strategies, and found that awareness of meta-cognitive strategies and meta-cognitive knowledge affects students' academic achievement. Maleki (2005) examined the effect of cognitive and meta-cognitive strategies on progress in various school subjects, including English, and found that neither cognitive nor meta-cognitive strategies were useful in learning a foreign language. Pishghadam (2009) looked into the relationship between the use of language learning strategies and gender and the preferred learning strategies for learning English as a foreign language. The findings indicated that meta-cognitive strategies were used more than other strategies, and affective strategies were used the least. In addition, men and women were found to be the same in terms of overall use of learning strategies, but men used memory and social strategies more often in comparison with other strategies. Salarifar and Pakdaman (2010) also studied meta-cognitive abilities in relation to academic performance, and the results indicated a positive association between academic performance and meta-cognitive abilities. Javadi, Keyvanara, Yaghoobbi, Hassanzade and Ebadi, (2010) looked at the correlation between students' academic attainment and meta-cognitive awareness of reading strategies, and they found that advanced students used more complex meta-cognitive and cognitive strategies than lower level students did. They also found a positive correlation between academic achievement and meta-cognitive awareness, but there was no correlation between meta-cognitive awareness and demographic variables (i.e., gender, age, and area of residence). Shirani Bidabadi and Yamat (2010) investigated the relationship between students' learning style preferences 
and the listening strategies they used, and found that English foreign language students most often employed meta-cognitive listening strategies such as directed attention, planning, and selective attention. Sutudenama and Taghipur (2010) investigated the relationship between meta-cognitive knowledge of learning strategies, motivation, and listening comprehension of foreign language learners. Their results indicated that students with an aptitude for listening differed from less talented students in terms of how they used strategies. They found that less gifted listeners used inappropriate strategies more often than gifted students, and skilled students used strategies more than less skilled students. Shirani Bidabadi and Yamat (2011) investigated the relationship between university students' learning strategies and their listening proficiency. They carried out a descriptive analysis on a sample of advanced, intermediate, and lower-intermediate university students, and they found that students use meta-cognitive strategies most frequently, followed by cognitive and socio-affective listening strategies. In addition, a positive correlation was found between students' language learning strategies and their levels of listening proficiency.

\section{Research methodology}

\section{Research problem and the aim of the study}

As can be inferred from the previous section, this study on meta-cognitive abilities and their impact on the development of foreign language skills makes a significant contribution to research into foreign language teaching and learning in general. In addition, the fact that the study was carried out on a large sample of university students in Serbia illustrates its relevance to this educational setting.

Therefore, the research question (problem) is: To what extent are meta-cognitive abilities significant for acquiring and developing foreign language skills? In order to answer this, nine elements of meta-cognitive strategy that have an impact on students' listening comprehension, reading, writing, and speaking abilities were investigated through relevant statements (SILL 30, 31,32, 33, 34, 35, 36, 37, 38) in the SILL questionnaire (Oxford, 1990). This study focused on the relationship between nine elements of meta-cognition and four self-assessed language skills. The effects of gender also contributed to the overall findings. The students' meta-cognitive reactions were investigated through nine statements concerning the following activities: centering language learning activity, arranging and planning language learning activity, understanding a problem and its analysis, considering a problem situation as a whole and finding a solution, being aware of the ways of using prior knowledge, finding the optimal solution to the problem, and organizing activities.

Therefore, the aim of this study is to examine the influence of meta-cognitive abilities on the development of language skills, or in other words, to understand how they are interrelated. In this respect, it is important to consider the interrelation between certain elements of meta-cognitive abilities and the level of development of students' listening comprehension, reading, writing, and speaking in a foreign language. The study looked at the use of meta-cognitive strategies investigated through the SILL questionnaire (Oxford, 
1990) as well as the effects of gender on the development of students' language skills as was stated through the students' self-assessment.

Three hypotheses were formulated and further tested in the study:

The first hypothesis $\mathrm{H} 1$ : There is a statistically significant relationship between the elements of meta-cognitive abilities and the four language skills: listening comprehension, reading, writing, and speaking.

The second hypothesis H2: There are statistically significant gender differences in mastering the four language skills.

The third hypothesis H3: There are statistically significant gender differences in the use of meta-cognitive strategies.

\section{Sample}

The sample was comprised of 401 university students (56.9\% female). The mean age of the participants was 19.77 years $(S D=2.02)$, and they were recruited from the Mihailo Palov Preschool Teacher Training College in Vršac $(n=106)$ and the Faculty of Technical Sciences in Novi Sad $(n=295)$.

\section{Data analysis}

SPSS (Statistical Package for Social Sciences) was employed to analyze the data. In order to address the research questions, descriptive statistics were calculated, and four multiple linear regressions were conducted. Regression analyses were meant to test the predictive role of meta-cognitive awareness in relation to the self-assessments of the foreign language skills used as criteria. T-tests were used to examine gender differences in foreign language skills and meta-cognitive abilities. When assessing gender differences, the dependent variables were 5- and 7-point scales. A t-test was used as studies show that when data distributions are not skewed, they have similar power to its nonparametric alternatives when used with this type of data (5-point scales) (de Winter \& Dodou, 2010).

\section{Instruments}

Data collection was conducted by using a questionnaire consisting of two parts. The first part contained demographic questions and students' self-assessment of four language skills, which was carried out through the following questions:

1. How do you assess your listening comprehension ability in the foreign language?

2. How do you assess your reading ability in the foreign language?

3. How do you assess your speaking ability in the foreign language?

4. How do you assess your writing in the foreign language?

Students responded using the seven-point Likert scale from very poor to excellent.

The second part of the questionnaire was Oxford's (1990) Strategy Inventory for Language Learning (SILL). There were originally two versions of the SILL, both for English speakers learning a new language (version 5.1) and for speakers of other 
languages learning English (version 7.0). For the current study, the SILL 7.0 version was employed. It was translated into Serbian to obtain more precise results. The SILL is a self-report questionnaire that measures the frequency of use of language learning strategies among adult second language learners (Oxford, 1990). Oxford's SILL (1990) has six strategy groups and fifty items. FLLS (Foreign Language Learning Strategies) are divided into two categories (direct and indirect). Direct strategies include Memory strategies (9 items; $a=.75$ ), Cognitive strategies (11 items; $a=.84$ ), and Compensation strategies ( 6 items; $a=.63$ ). Indirect strategies are comprised of Meta-cognitive strategies (9 items; $a=.86$ ), Affective strategies ( 6 items; $a=.70$ ) and Social strategies ( 6 items; $a=$ .75). Only the nine items assessing meta-cognitive strategies were used in this study.

\section{Results}

\section{Descriptive statistics}

The results of descriptive statistics (Table 1) indicate that there are no univariate deviations from the normal distribution in variables, as values of skewness and kurtosis are in the suggested range of \pm 1.5 (Tabachnick \& Fidell, 2013).

Table 1. Descriptive statistics for the main variables

\begin{tabular}{llll}
\hline Item & Mean (SD) & Skewness & Kurtosis \\
\hline $\begin{array}{l}\text { SILL 30 I try to find as many ways as I can to use } \\
\text { my English/German. }\end{array}$ & $3.40(1.27)$ & -.28 & -.94 \\
\hline $\begin{array}{l}\text { SILL 31 I notice my English/German mistakes and use that } \\
\text { information to help me do better. }\end{array}$ & $3.60(1.19)$ & -.52 & -.62 \\
\hline $\begin{array}{l}\text { SILL 32 I pay attention when someone is speaking } \\
\text { English/German. }\end{array}$ & $3.84(1.12)$ & -.77 & -.14 \\
\hline $\begin{array}{l}\text { SILL 33. I try to find out how to be a better learner of } \\
\text { English/German. }\end{array}$ & $3.61(1.25)$ & -.56 & -.70 \\
\hline $\begin{array}{l}\text { SILL 34. I plan my schedule so I will have enough time } \\
\text { to study English/German. }\end{array}$ & $2.50(1.23)$ & .37 & -.82 \\
\hline SILL 35. I look for people I can talk to in English/German. & $2.85(1.37)$ & .14 & -1.12 \\
\hline $\begin{array}{l}\text { SILL 36. I look for opportunities to read as much as possible } \\
\text { in English/German. }\end{array}$ & $2.84(1.29)$ & .16 & -1.00 \\
\hline SILL 37. I have clear goals for improving my English/German skills. & $3.15(1.26)$ & -.18 & -.89 \\
\hline SILL 38. I think about my progress in learning English. & $3.51(1.23)$ & -.44 & -.75 \\
\hline How do you assess your listening comprehension ability & $5.02(1.72)$ & -.54 & -.74 \\
\hline \begin{tabular}{l} 
in the foreign language? \\
\hline How do you assess your reading ability in the foreign language?
\end{tabular} & $5.32(1.66)$ & -.74 & -.40 \\
\hline How do you assess your speaking ability in the foreign language? & $4.32(1.75)$ & -.14 & -.96 \\
\hline How do you assess your writing ability in the foreign language? & $4.40(1.77)$ & -.21 & -.89 \\
\hline
\end{tabular}

Note: Mean (SD) - Mean and standard deviation. 


\section{Relations between elements of meta-cognitive learning strategy and self-assessment of four language skills}

In order to examine which meta-cognitive strategy items were best predictors of different assessments of four language skills, four multiple linear regressions were performed. The dependent variables were four items that assessed students' language abilities. All four models reached statistical significance and explained $21-36 \%$ of the variance of the criterion variables.

Table 2. Summary of four regression models

\begin{tabular}{lccccc}
\hline Criterion & $\mathrm{R}^{2}$ & $\mathrm{~F}$ & $\mathrm{df1}$ & $\mathrm{df2}$ & $\mathrm{p}$ \\
\hline $\begin{array}{l}\text { How do you assess your listening comprehension ability } \\
\text { in the foreign language? }\end{array}$ & .329 & 21.21 & 9 & 390 & .000 \\
\hline $\begin{array}{l}\text { How do you assess your reading ability in the foreign } \\
\text { language? }\end{array}$ & .210 & 11.49 & 9 & 390 & .000 \\
\hline $\begin{array}{l}\text { How do you assess your speaking ability in the foreign } \\
\text { language? }\end{array}$ & .365 & 24.92 & 9 & 390 & .000 \\
\hline $\begin{array}{l}\text { How do you assess your writing ability in the foreign } \\
\text { language? }\end{array}$ & .305 & 19.03 & 9 & 390 & .000 \\
\hline
\end{tabular}

Note: $R^{2}$ - Coefficient of determination; $F, d f 1, d f 2$ - F test and degrees of freedom; $p$ - significance level.

The values of beta coefficients for all regression models are presented in table 3. Items SILL 30 "I try to find as many ways as I can to use my English/German", SILL 31 "I notice my English/German mistakes and use that information to help me do better", SILL 32 "I pay attention when someone is speaking English/German", and SILL 36 "I look for opportunities to read as much as possible in English/German" were statistically significant in predicting all four criterion variables. Item SILL 33 "I try to find out how to be a better learner of English/German" was a significant predictor only for criterion 2, which is associated with the self-assessment of reading abilities. Since all of these relationships are positively oriented, people who score higher on these items are more likely to score higher on self-assessment items after controlling for other variables in the model.

Table 3. Relative predictive power of meta-cognitive strategy items for four types of language mastery

\begin{tabular}{lcccc}
\hline \multicolumn{5}{c}{$\beta$} \\
\hline Predictor & Criterion 1 & Criterion 2 & Criterion 3 & Criterion 4 \\
\hline SILL 30 & $.304^{* *}$ & $.175^{* *}$ & $.325^{* *}$ & $.239^{* *}$ \\
\hline SILL 31 & $.135^{*}$ & $.181^{* *}$ & $.171^{* *}$ & $.183^{* *}$ \\
\hline SILL 32 & $.173^{* *}$ & $.121^{*}$ & $.148^{* *}$ & $.127^{*}$ \\
\hline SILL 33 & -.102 & $-.150^{*}$ & -.085 & -.097 \\
\hline SILL 34 & -.092 & -.046 & -.047 & -.021 \\
\hline SILL 35 & .099 & .077 & .099 & .095 \\
\hline SILL 36 & $.189^{* *}$ & $.178^{* *}$ & $.175^{* *}$ & $.190^{* *}$ \\
\hline SILL 37 & -.080 & -.020 & -.081 & -.049 \\
\hline SILL 38 & -.048 & -.044 & -.054 & -.025 \\
\hline
\end{tabular}


Note: Criterion 1 - How do you assess your listening comprehension ability in the foreign language?; Criterion 2 - How do you assess your reading ability in the foreign language?; Criterion 3 - How do you assess your speaking ability in the foreign language?; Criterion 4 - How do you assess your writing ability in the foreign language?; ${ }^{*}-p<0.05 ;^{* *}-p<0.01$.

\section{Gender differences in mastering the four language skills}

Four independent sample t-tests were conducted to determine if statistically significant gender differences existed in four aspects of English language mastery (Table 4). In order to test the assumption of homogeneity of variance, Levene's test was conducted. Levene's test was significant $(p<.05)$ for the dependent variables "How do you assess your speaking ability in the foreign language?", and "How do you assess your reading ability in the foreign language?", so the results when equal variances are not assumed have been presented for these cases. The results indicate that there are significant differences in self-assessed mastery of four language skills and that men scored higher than women on all four variables.

Table 4. Gender differences in four aspects of English language mastery

\begin{tabular}{|c|c|c|c|c|c|c|}
\hline & Group & Mean & SD & t-test & df & $p$ \\
\hline \multirow{2}{*}{$\begin{array}{l}\text { How do you assess your listening } \\
\text { comprehension ability in the foreign language? }\end{array}$} & Male & 5.49 & 1.58 & \multirow{2}{*}{4.97} & \multirow{2}{*}{386.4} & \multirow{2}{*}{.000} \\
\hline & Female & 4.66 & 1.74 & & & \\
\hline \multirow{2}{*}{$\begin{array}{l}\text { How do you assess your reading ability in the foreign } \\
\text { language? }\end{array}$} & Male & 5.72 & 1.52 & \multirow{2}{*}{4.39} & \multirow{2}{*}{388.2} & \multirow{2}{*}{.000} \\
\hline & Female & 5.01 & 1.70 & & & \\
\hline \multirow{2}{*}{$\begin{array}{l}\text { How do you assess your speaking ability in the foreign } \\
\text { language? }\end{array}$} & Male & 4.73 & 1.63 & \multirow{2}{*}{4.13} & \multirow{2}{*}{399} & \multirow{2}{*}{.000} \\
\hline & Female & 4.01 & 1.77 & & & \\
\hline \multirow{2}{*}{$\begin{array}{l}\text { How do you assess your writing ability in the foreign } \\
\text { language? }\end{array}$} & Male & 4.79 & 1.69 & \multirow{2}{*}{3.87} & \multirow{2}{*}{399} & \multirow{2}{*}{.000} \\
\hline & Female & 4.11 & 1.78 & & & \\
\hline
\end{tabular}

Note: Mean - Mean value of the group; SD - standard deviation of the group; t-test, df - t-test value and degrees of freedom; $\mathrm{p}$ - significance level.

\section{Gender differences in the use of meta-cognitive strategies}

Eight independent sample t-tests were conducted to determine whether significant gender differences existed in eight aspects of meta-cognitive learning strategies. In order to test the assumption of homogeneity of variance Levene's test was conducted. Levene's test was significant $(p<.05)$ for dependent variables, SILL 30 "I try to find as many ways as I can to use my English/German" and SILL 38"I think about my progress in learning English", so the results when equal variances are not assumed are presented for these cases. The results indicate there are significant gender differences for item SILL 30 "I try to find as many ways as I can to use my English/German" $(\mathrm{t}(391.21)=2.86, \mathrm{p}<.05)$ and that men (M $=3.61, \mathrm{SD}=1.16)$ scored higher than women $(M=3.25, \mathrm{SD}=1.33)$ on this variable. The test is not statistically significant for any of the other variables $(p>.05)$. 
Table 5. Gender differences in different aspects of meta-cognitive strategy

\begin{tabular}{|c|c|c|c|c|c|c|}
\hline & Group & Mean & SD & t-test & $d f$ & $p$ \\
\hline \multirow{2}{*}{ SILL 30} & Male & 3.61 & 1.16 & \multirow{2}{*}{2.86} & \multirow{2}{*}{391.21} & \multirow{2}{*}{.004} \\
\hline & Female & 3.25 & 1.33 & & & \\
\hline \multirow{2}{*}{ SILL 31} & Male & 3.68 & 1.14 & \multirow{2}{*}{1.18} & \multirow{2}{*}{399} & \multirow{2}{*}{.236} \\
\hline & Female & 3.54 & 1.23 & & & \\
\hline \multirow{2}{*}{ SILL 32} & Male & 3.80 & 1.07 & \multirow{2}{*}{-.66} & \multirow{2}{*}{398} & \multirow{2}{*}{.511} \\
\hline & Female & 3.87 & 1.16 & & & \\
\hline \multirow{2}{*}{ SILL 33} & Male & 3.50 & 1.25 & \multirow{2}{*}{-1.59} & \multirow{2}{*}{399} & \multirow{2}{*}{.111} \\
\hline & Female & 3.70 & 1.24 & & & \\
\hline \multirow{2}{*}{ SILL 34} & Male & 2.54 & 1.19 & \multirow{2}{*}{.55} & \multirow{2}{*}{399} & \multirow{2}{*}{.582} \\
\hline & Female & 2.47 & 1.26 & & & \\
\hline \multirow{2}{*}{ SILL 35} & Male & 2.86 & 1.31 & \multirow{2}{*}{.20} & \multirow{2}{*}{399} & \multirow{2}{*}{.841} \\
\hline & Female & 2.83 & 1.43 & & & \\
\hline \multirow{2}{*}{ SILL 36} & Male & 2.92 & 1.28 & \multirow{2}{*}{1.09} & \multirow{2}{*}{399} & \multirow{2}{*}{.273} \\
\hline & Female & 2.78 & 1.29 & & & \\
\hline \multirow{2}{*}{ SILL 37} & Male & 3.14 & 1.19 & \multirow{2}{*}{-.186} & \multirow{2}{*}{399} & \multirow{2}{*}{.853} \\
\hline & Female & 3.16 & 1.31 & & & \\
\hline \multirow{2}{*}{ SILL 38} & Male & 3.53 & 1.13 & \multirow{2}{*}{.249} & \multirow{2}{*}{392.48} & \multirow{2}{*}{.803} \\
\hline & Female & 3.50 & 1.31 & & & \\
\hline
\end{tabular}

The results show that:

The first hypothesis H1: "There is a statistically significant relationship between the elements of meta-cognitive abilities and the four language skills: listening comprehension, reading, writing and speaking" was confirmed.

The second hypothesis $\mathrm{H} 2$ : "There are statistically significant gender differences in mastering the four language skills" was confirmed.

The third hypothesis H3: "There are statistically significant gender differences in the use of meta-cognitive strategies" was rejected.

\section{Discussion}

As an important affective factor, gender has a specific role and impact on second language learning. The study answered the question about the existence of a relationship between gender and students' perception of the development of their language skills. The results showed that men scored higher on all four variables, which indicates they were better at assessing their language skills than women were. The results are in line with findings by Nyikos, (1990) and Bacon and Finnemann (1992), who found that men scored better in overall language ability or specific language skills. However, it should be noted that three quarters of respondents in the sample used the foreign language on a 
daily basis, since they were engineering students studying IT. They were almost all male and students with high achievements in other subjects as well. Based on previous evidence, most people believe that women are more successful language learners, and this has been found in many previous studies. Nevertheless, the findings related to female superiority in learning languages cannot be generalized to all settings or evaluated on their own, since the opposite has also been found. The findings of our study failed to support the general belief that women are superior language learners. So far, scholars studying foreign languages have reported that gender differences clearly influence students' academic needs, interests, and achievements even though gender differences are primarily culturally or biologically determined.

The results provide evidence that some of the elements of meta-cognitive abilities represent statistically significant predictors of different language skills: listening comprehension, reading, writing, and speaking. Four elements of meta-cognitive strategy (SILL 30 "I try to find as many ways as I can to use my English/German", SILL 31 "I notice my English/ German mistakes and use that information to help me do better", SILL 32 "I pay attention when someone is speaking English/German", and SILL 36 "I look for opportunities to read as much as possible in English/German" relating to the Centering learning and Arranging and planning learning domains proved to be significant predictors for the development of all four language skills. The element SILL 33 "I try to find out how to be a better learner of English/German" was found to be an important predictor of students' reading abilities.

Five out of nine elements of meta-cognitive strategy were found to be predictive for the self-assessment of language skills, which is also a significant finding and may contribute to an overall conclusion that the use of meta-cognitive strategies is important in building language skills. Our findings are in line with the results of other studies (Anderson, 2003; Rasekh \& Ranjbary, 2003) that focused on how successful and advanced language learners approach reading, writing, speaking, and listening activities in regard to the type of strategies they use. Comparable findings (Goh 1998, 1999; O'Malley et al., 1989) have also been reported in various studies investigating second language listening skills. The overall findings of this study indicate that high degrees of meta-cognitive awareness enable students to practice and reinforce the knowledge they have already attained as well as process and store new information. In addition, this awareness has an important role in enhancing thinking and comprehension abilities. This is in line with the findings of previous studies which support the conclusion that good language learners are fully aware of the steps they take while applying an extensive range of strategies when reading, writing, speaking, and listening in the foreign language (Vandergrift, 1996, 1997; Young, 1997).

When dealing with gender differences in the use of meta-cognitive strategies, only one of the nine elements was found to be significant, which means that this study failed to discover evidence of differences between genders in the use of language learning strategies. This finding is in line with most previous studies (Ehrman \& Oxford, 1990; Javadi et al., 2010; Pishghadam, 2009). It should be noted that, although men and women are unlikely to show differences in the use of language learning strategies, in the studies where these differences are reported, women tend to use more language learning strategies in comparison with men (Ehrman \& Oxford, 1989; Green \& Oxford, 1995; Oxford \& Nyikos, 1989). 


\section{Conclusion and pedagogical implications}

In conclusion, students' meta-cognitive reactions demonstrate their awareness and understanding when dealing with language learning activities in the following ways: being aware of the aim to be achieved and the ways in which the aim will be achieved, analyzing what the problem consists of, raising new questions, employing a strategy of meaningful organization, and reconsidering of the task (i.e. dealing with other possibilities). The findings confirm that in comparison with less successful students, proficient language learners are fully aware of the steps they take when using a wide range of strategies. Less proficient students use fewer learning strategies and do not think much about the outcome of a learning activity. The findings of the study indicate that awareness of meta-cognitive strategies and meta-cognitive knowledge affect students' academic achievement, and that meta-cognitive strategies are effective as a learning tool.

Meta-cognitive abilities are constantly developing, and didactic instructions play an important role in teaching and nurturing meta-cognitive functions. Didactic instructions should encourage students to identify a problem, explain its meaning, consider the sources of dilemmas, explain the sense of confusion and tension, provoke through controversy, and realize the ways in which actions are regulated and managed, which leads to a solution of the problem (Gojkov, 1995). Meta-cognition should be considered a link between students' abilities and achieved (executive) intelligence (Gojkov, 2001). Therefore, the possibilities for didactic instructions that encourage meta-cognitive ability are significant. Teaching students to master thinking skills is the key point in developing meta-cognitive insights. Being reflective about what has been done and what needs to be improved is important in the development of awareness, and students' concrete and abstract understanding is fostered through this process. Implementing meta-cognitive teaching in language learning activities can result in the achievement of desirable learning objectives, and raising meta-cognitive awareness can improve the level of students' achievement in language learning. Problem-solving activities and task performance are directly related to precise and well-organized meta-cognitive strategies. Providing enough opportunities for students to master meta-cognitive strategies can assure high-quality performance as well as help them to retrieve information when they have memory problems. In the field of autonomy, students develop confidence and motivation in second language learning. 


\section{References}

Akbari, R. (2003). The relationship between the use of language learning strategies by Iranian learners of English, their foreign language proficiency, and the learners' IQ scores. IJAL, 6, 1-20.

Anderson, N. J. (2003). Meta-cognitive reading strategies increase L2 performance. The Language Teacher, 27, 20-22.

Bacon, S.M.C. \& Finnemann, M.D. (1992). Sex differences in self-reported beliefs about language learning and authentic oral and written input. Language Learning, 42(4), 471-495.

Baker, L., \& Brown, A. (1984). Metacognitive skills and reading. In P. D. Pearson (Ed.), Handbook of Reading Research. New York: Longman.

Birjandi, P., Mirhassani, A. \& Abbasian, G. (2006). Setting-based metacognitive strategy use. Journal of Faculty of Letters and Humanities, 49(198), 39-87.

Boekaerts, M., Pintrich, P. \& Zeidner, M. (2000). Handbook of self-regulation. San Diego: Academic Press.

Bolitho, R., Carter, R., Hughes, R., Ivanic, R., Masuhara, H., \& Tomlinson, B. (2003). Ten questions about language awareness. ELT Journal, 57(3), 251-260.

Chari, M., Samavi, A. \& Kordestani, D. (2010). Investigating psychometric characteristics of metacognitive reading strategies scale among Iranian high-school students. Psychiatry Studies, 6, 1-22.

Costa, A. L. (Ed.) (2001). Developing minds: A resource book for teaching thinking (3rd ed.). Alexandria, VA: Association for Supervision and Curriculum Development.

Dickinson, L. (1995). Autonomy and motivation: A literature review. System, 23, 165-74.

Eilam, B., \& Aharon, I. (2003). Students' planning in the process of self-regulated learning. Contemporary Educational Psychology, 28, 304-334.

Ehrman, M. \& Oxford, R. (1989). Effects of sex differences, career choice, and psychological type on adults' language learning strategies. Modern Language Journal, 73(1), 1-13.

Ehrman, M. E. \& Oxford, R. L. (1990). Adult language learning styles and strategies in an intensive training setting. Modern Language Journal, 74(3), 311-327.

Flavell, J. H. (1976). Metacognitive aspects of problem-solving. In L. B. Resnick (Ed.), The nature of intelligence. Hillsdale, NJ: Erlbaum.

Flavell, J. H. (1979). Metacognition and cognitive monitoring: A new area of cognitive-developmental inquiry. American Psychologist, 34, 906 - 911.

Goh, C. (1998). How learners with different listening abilities use comprehension strategies and tactics. Language Teaching Research, 2, 124- 47.

Goh, C. (1999). What learners know about the factors that influence their listening comprehension? Hong Kong Journal of Applied Linguistics, 4, 17-42.

Goh, C. (2008). Metacognitive instruction for second language listening development: Theory, practice and research implications. Regional Language Centre Journal, 39(2), 188-213.

Gojkov, G., (1995). Metakognicija i strategijski transfer u didaktičkim kompetencijama nastavnika, Inovacije u nastavi, 5.

Gojkov, G., (2001). Didaktički aspekt metakognicije darovitih, Pedagoška stvarnost, 9-10, 675-696. 
Gojkov, G., (2008). Didaktika darovitih, Visoka škola strukovnih studija za obrazovanje vaspitača, Vršac.

Gojkov, G., (2010). Metacognition as a link between ability and successful (executive) intelligence. Didactica Slovenica - Pedagoška obzorja, 25(2), 131-150.

Gojkov, G., \& Stojanović, A. (2011). Kreativne karakteristike kognitivnog stila i metakognicija darovitih, u Zbornik br.16 "Daroviti u procesu globalizacije" 195-241.

Green, J. M. \& Oxford, R. L. (1995). A closer look at learning strategies, L2 proficiency, and gender. TESOL Quarterly, 29(2), 261-297.

Javadi, M., Keyvanara. M., Yaghoobbi, M., Hassanzade, A. \& Ebadi, Z. (2010). The relationship between meta-cognitive awareness of reading strategies and students' academic status in Isfahan University of Medical Sciences. Iranian medical science journal, 3(10), 246-254.

Lachini, K. (1997). The impact of language proficiency on language Communication and learning strategies. Unpublished doctoral dissertation. Islamic Azad University, Tehran, Iran.

Mahmoudi, E. \& Khonamri, F. (2010). The relationship between meta-cognitive awareness of reading strategies and comprehension monitoring in reading ability of EFL learners. Paper presented The 8th International TELLSI Conference, Al-Zahra University, Tehran, Iran.

Maleki, B. (2005). The effect of cognitive and meta-cognitive strategies on improvement of different school subjects. New findings in cognitive science, 7(3), 42-49.

Mokhtari, K., \& Reichard, C. (2002). Assessing students' meta-cognitive awareness of reading strategies. Journal of Educational Psychology, 94, 249-259.

Nickerson, R. S., Perkins, D.N., \& Smith, E.E. (1985). The teaching of thinking. Hillsdale, NJ Lawrence Erlbaum Associates.

Nyikos, M. (1990) Sex related differences in adult language learning; socialization and memory factors. The Modern Language Journal, 74(3), 273-287.

O'Malley, J. M., Chamot, A. U. \& Küpper, L. (1989). Listening comprehension strategies in second language acquisition. Applied Linguistics, 10(4), 418-437.

Oxford, R. \& Nyikos, M. (1989). Variables affecting choice of language learning strategies by university students. The Modern Language Journal, 73(3), 291-300. http://dx.doi. org/10.1111/j.1540-4781.1989.tb06367.x

Oxford, R. (1990). Language learning strategies, What every teacher should know. Heinle and Heinle Publishers. A Division of Wadsworth, Inc. Boston.

Palmer, D. J. \& Goetz, E.T. (1988). Selection and use of study strategies:The role of the studier's beliefs about self and strategies. In C. E. Weinstein, E. T. Goetz \& P. Alexander (Eds.), Learning and study strategies: Issues in assessment, instruction, and evaluation (pp. 77-100). Orlando, FL: Academic Press.

Pintrich, P. R., Marx, R.W. \& Boyle, R.A. (1993). Beyond cold conceptual change: The role of motivational beliefs and classroom contextual factors in the process of conceptual change. Review of Educational Research, 63, 167-200.

Pishghadam, R. (2009). The relationship between the use of learning strategies with gender for learning English and the preferred learning strategies for learning English by Iranian students. Journal of the Literature and Humanities Faculty of Tabriz University, 208, 24-50. 
Purpura, J. (1997). An analysis of the relationships between test takers' cognitive and meta-cognitive strategy use and second language test performance. Language Learning, 47, 289-325.

Purpura, J. (1998). Investigating the effects of strategy use and second language test performance with high- and low-ability test-takers: A structural equation modeling approach. Language Testing, 15, 333-379

Rasekh, Z. \& Ranjbary, R. (2003). Meta-cognitive strategy training for vocabulary learning, TESL-EJ, 7, 1-18.

Salarifar, M. H. \& Pakdaman, Sh. (2010). The role of meta-cognitive state components on academic performance. Journal of Applied Psychology, 3(4), 102-112.

Schommer, L.(1990). Effects of beliefs about the nature of knowledge on comprehension. Journal of Educational Psychology, 82, 498-504.

ShiraniBidabadi, F. \& Yamat, H. (2010). The relationship between listening strategies employed by Iranian EFL freshman university students and their learning style preferences. European Journal of Social Sciences, 16(3), 342-351.

ShiraniBidabadi, F. \& Yamat, H. (2011). The relationship between listening strategies used by Iranian EFL freshman university students and their listening proficiency levels. English Language Teaching, 4(1), 26-32.

Sternberg, R. J. (1998). Meta-cognition, abilities and developing expertise: What makes an expert student? Instructional Science, 26, 127- 140.

Sutudenama, E. \& Taghipur, F. (2010). The relationship between motivation, metacognitive knowledge of learning strategies and listening comprehension of Iranian learners of English. Language Research Journal of Alzahra University, 1(2), 25-52.

Tabachnick, B. G. \& Fidell, L. S. (2013). Using multivariate statistics, 6th ed. Boston: Pearson.

Tajedin, Z. (2001). Language learning strategies: A strategy-based approach to L2 learning, strategic competence, and test validation. Unpublished doctoral dissertation. Allameh Tabatabaee University, Tehran, Iran.

Vann, R. \& Abraham, R. (1990). Strategies of unsuccessful language learners. TESOL Quarterly, 24, 177-98.

Vandergrift, L. (1996). The listening comprehension strategies of core French high school students, Canadian Modern Language Review, 52, 200-23.

Vandergrift, L. (1997). The Strategies of Second Language (French) listeners: A Descriptive Study. Foreign Language Annals, 30, 387-409.

Vandergrift, L., Goh, C. C. M., Mareschal, C. \& Tafaghodtari, M. H. (2006). The meta-cognitive awareness listening questionnaire (MALQ): Development and Validation. Language Learning, 56(3), 431-462.

Wenden, A. (1998). Meta-cognitive knowledge and language learning. Applied Linguistics, 19(4), 515-537.

de Winter, J. C. F. \& Dodou, D. (2010). Five-Point Likert Items: t Test versus Mann-Whitney-Wilcoxon. Practical Assessment, Research and Evaluation, 15(11), 1-7.

Young, M.Y.C. (1997). A serial ordering of listening comprehension strategies used by advanced ESL learners in Hong Kong. Asian Journal of English language Teaching, 7, 35-53. 
Zare, H. \& Sarmadi, M. R. (2004). The difference between weak and strong Payame Nour University students in their meta-cognitive knowledge and meta-cognitive strategies awareness. Nour review, 3(2).

Zhang, D. \& Goh, C. (2006). Strategy knowledge and perceived strategy use: Singaporean students' awareness of listening and speaking strategies. Language Awareness, 15, 199-219.

Zimmerman, B. J. \& Bandura, A. (1994). Impact of self-regulatory influences on writing course attainment. American Educational Research Journal, 31, 845-862.

Zimmerman, B. J. \& Schunk, D. H. (2001). Self-regulated learning and academic achievement. Mahwah, NJ: Erlbaum.

Примљено: 31. 12. 2017. Коригована верзија текста примљена: 25. 04. 2018. Прихваћено за штампу: 30. 04. 2018. 


\title{
УТИЦАЈ МЕТАКОГНИТИВНИХ СПОСОБНОСТИ И ПОЛА СТУДЕНАТА НА РАЗВОЈ ЈЕЗИЧКИХ ВЕШТИНА
}

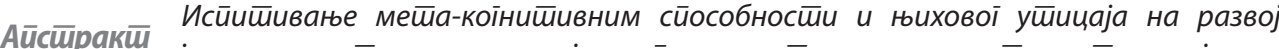

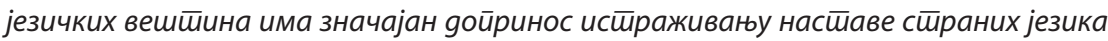

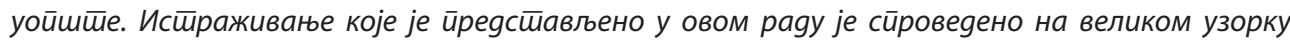

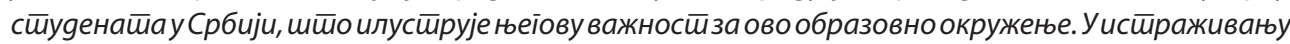

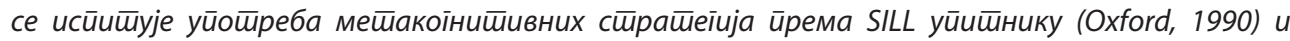

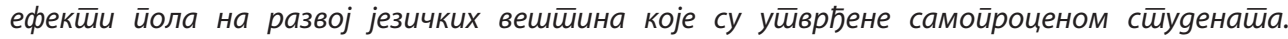

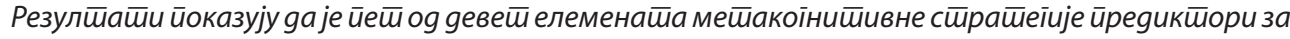

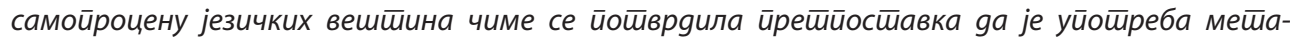

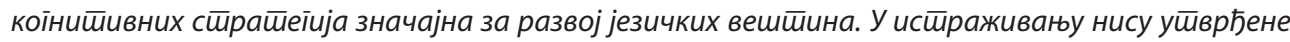

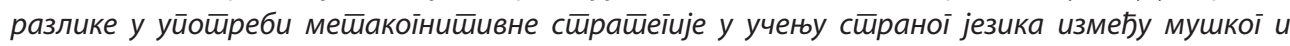

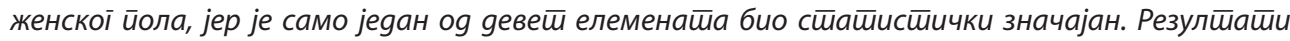
указују на йосӣојање овноса између ӣола и ӣерцеӣције сйуденайа о юиховом језичким

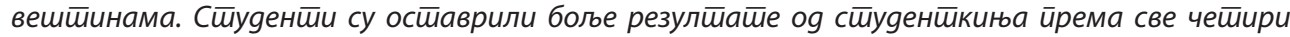
исйишиване варијабле, шито значи gа су боље оценили своје језичке вешиине. Пеgаїошке

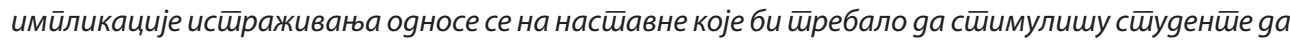

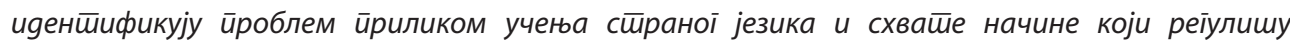

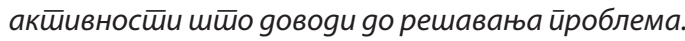

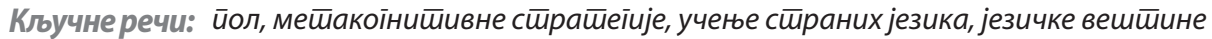

\section{ВЛИЯНИЕ МЕТАКОГНИТИВНЫХ СПОСОБНОСТЕЙ И ПОЛА НА РАЗВИТИЕ ЯЗЫКОВЫХ НАВЫКОВ У СТУДЕНТОВ}

\begin{abstract}
Резюме
Исследование метакогнитивных способностей и их влияния на развитие языковых навыков вносит значительный вклад в изучение методики преподавания иностранных языков в челом. Представленное в данной работе исследование проведено на большом числе студентов, что иллюстрирует его важность в сербской образовательной среде. В исследовании рассматривается применение метакогнитивных стратегий согласно SILL вопроснику (Оксфорд, 1990), а также влияние гендерного фактора на развитие языковых навыков, уровень которых определяется самооценкой студентов. Результаты показывают, что пять из девяти элементов метакогнитивных стратегий является предиктором для самооченки языковых навыков, что подтверждает предположение о важности использования метакогнитивных стратегий для развития языковых навыков. В исследовании не обнаружена гендерная разница в использовании метакогнитивных стратегий в изучении иностранного языка, так как только один из девяти элементов был статистически значимым. Полученные результаты указывают на наличие связи между полом и восприятием студентами их языковых навыков. По сравнению с студентками, студенты добились лучших результатов по всем 4 изученным переменным, а это значит, что вернее оценили уровень своих языковых навыков. Педагогические последствия исследования, связанные с преподавателем, касаются его обязанности стимулировать студента при определении проблем в изучении иностранного языка и выборе способа регулирования активностей, ведущих крешению проблем.
\end{abstract}

Ключевыеслова: пол, метакогнитивные стратегии, изучение иностранных языков, языковые навыки 